variation in normal range. Consequently the clinical significance of a particular level of haptoglobin is less important than change from that level. In general changes in haptoglobin levels correlate with changes in CRP and ESR. ${ }^{2} 3$;

All groups contained patients with a wide range of radiological damage at the onset of the study but we cannot say what the CRP and ESR levels had been during the development of that damage. The mere presence of joint erosions apparently does not itself raise CRP and ESR levels. Several methods of assessing radiographic changes have been described, some of them extremely detailed. Sharp, ${ }^{15}$ for example, gave a possible score of 290 for each hand based on joint space, juxta-articular osteoporosis, soft tissue changes, and erosions. Some of these are particularly difficult to assess. Counting all clear-cut erosions in the hands and wrists seemed to provide a simple and practical alternative. Possibly other joints may have been damaged, but it is unusual for a patient with widespread rheumatoid arthritis to have little or no evidence of disease in the hands or wrists.

Our findings may help to explain the different effects of different drugs. Only drugs capable of lowering acute-phase protein levels could be expected to have any effect on the evolution of $x$-ray changes. Even then CRP and ESR levels would have to be substantially reduced for at least a year before any such effect could be recognised in an individual; in groups of patients with variable responses to a drug recognising an effect would be more difficult.
Regional Health Authority to this work. Dr J Egginton gave valuable advice in the early stages.

\section{References}

${ }^{1}$ Soothill, J F, Lectures on the Scientific Basic of Medicine, p 276. London, Athlone Press, 1967.

2 Aronsen, K F, et al, Scandinavian fournal of Clinical and Laboratory Investigation, 1972, 20, suppl No $124, \mathrm{p} 124$.

${ }^{3} \mathrm{Koj}, \mathrm{A}$, in Structure and Function of Plasma Proteins, vol 1, ed A C Allison, $p$ 73. London and New York, Plenum Press, 1974.

${ }^{4}$ Hardwicke, J, and Squire, J R, Clinical Science, 1952, 2, 333.

${ }^{5}$ McConkey, B, Crockson, R A, and Crockson, A P, Quarterly fournal of Medicine (New Series), 1972, 41, 115.

${ }^{6}$ Ritchie, D M, et al, Quarterly fournal of Medicine (New Series), 1968, 37, 393.

' McConkey, B, et al, Quarterly fournal of Medicine (New Series), 1973, 42, 785.

${ }^{8}$ Paulus, H E, and Whitehouse, M W, Search for New Drugs, ed A A Rubin, p 1. New York, Marcel Decker, 1972.

${ }^{9}$ American Rheumatism Association, Annals of the Rheumatic Diseases, $1959,18,49$.

${ }^{10}$ Constable, T J, et al, Lancet, 1975, 1, 1176

${ }^{11}$ Crockson, R A, and Crockson, A P, Annals of the Rheumatic Diseases, 1974, 33, 53.

${ }_{12}$ Zacharski, L R, British fournal of Hospital Medicine, 1976, 16, 53.

${ }^{13}$ Crockson, R A, Fournal of Clinical Pathology, 1963, 16, 287.

${ }^{14}$ Mancini, G, Carbonata, A O, and Heremans, J F, Immunochemistry, 1965, 2, 235 .

${ }^{15}$ Sharp, J T, et al, Arthritis and Rheumatism, 1971, 14, 706.

\title{
Continuous intrauterine copper contraception for 3 years: comparison of replacement at 2 years with continuation of use
}

\author{
JOHN NEWTON, RUTH ILLINGWORTH, JULIAN ELIAS, JOHN MCEWAN
}

British Medical fournal, 1977, 1, 197-199

\section{Summary}

A total of 1245 women who had a copper 7 intrauterine contraceptive device (IUD) inserted in 1971-3 were followed up for three years (22 761.5 women months of use). After 24 months 483 women elected to continue with the same copper 7 (continuation group), and 183 had their copper 7 replaced with a new one (replacement group). The subsequent pregnancy and expulsion rates were both significantly lower in the replacement group. The higher pregnancy rate among the women who continued to use their copper 7 device for a third year suggests that although the copper is still there, it is not available for contraceptive action. Replacing the device at 24 months did not seem to cause again the problems that usually occur in the first six months of IUD use.

\footnotetext{
World Health Organisation Collaborating Centre for Clinical Research and Department of Obstetrics and Gynaecology, King's College Hospital, London SE5

JOHN NEWTON, MD, MRCOG, senior lecturer and director of centre RUTH ILLINGWORTH, SRN, SCM, research nurse

JULIAN ELIAS, MRCOG, WHO research fellow

JOHN MCEWAN, MB, MRCGP, consultant in family planning
}

\section{Introduction}

We have described our results with the copper 7 intrauterine device (IUD). ${ }^{12}$ Recent reports ${ }^{3}$ indicate that the useful life of a copper 7 may be three to four years, while Cooper et al ${ }^{4}$ predict an even longer useful life for the copper T $220 \mathrm{C}$. Recent reports of calcium deposition on copper devices, however, throw doubt on this longer life span of copper IUDs. ${ }^{5}$

To investigate the effect of time on the pregnancy rate and other medical side effects, we have collected data from the patients we originally studied ${ }^{2}$ during their third year of using a copper 7 device.

\section{Patients and method of analysis}

All patients who enrolled in the original copper 7 study and continued with the copper 7 were followed for at least 36 months. From January 1971 to March 19731245 women had a copper 7 inserted. When all patients had used the copper 7 for 24 months they were given a choice of continuing with the same device (continuation group) or having the device replaced with a new copper 7 (replacement group). At 1 April 1976 there were 443 women in the continuation group and 183 in the replacement group. All patients were seen each month for the first three months after insertion or replacement and thereafter every three months for three years. Cervical smears were taken every year. Our previous analyses were confined to first segments of use, but this report includes first and subsequent segments of use as described by Tietze $e t \mathrm{al}^{7}$; these reflect the actual use of this copper IUD in clinical practice. 
In evaluating the continuing use of contraception closure of the method (when a woman stops using an IUD) is more important than an event (which is followed by a reinsertion of an IUD). ${ }^{8}$ In clinical practice with the copper 7 the major change is seen in a lower net rate for expulsion when first and subsequent segments are analysed. The ability of the patient to accept a second device after expulsion and to continue with the method was shown in our earlier report. $^{2}$ All insertions took place in our hospital family planning clinics.

Data were analysed by conventional Tietze-Potter life table analysis producing "net" and "gross" rates. ${ }^{9} 10$ The computer programmes were designed in this department using a WANG 2200 computer. Medical removals were divided into removals for pain, bleeding, and pain plus bleeding to obtain more accurate information on the importance of these individual symptoms, which have been classified together in the past.

\section{Results}

The tables show the life table analyses for the individual groups by time of use; all rates were for closures of method. Table I shows the net rates for all insertions (1245 patients) significant to 36 months of use and represented by 22761 women months of use. The accidental pregnancy rate rose from 2.7 at 12 months of use to 5.5 at 36 months of use, but the annual pregnancy rate was higher in the first year of use, remaining the same (1.4) for the second and third year. Most of the expulsions $(76 \%)$ occurred in the first year of use, and most of these were within the first six months. Medical removals for pain were equal in rate to those for bleeding and showed a gradual rise during the whole three years of use, whereas removals for pain plus bleeding were less important ( 33 removals $v 113$ for the other two groups). Thirty-three patients required removals for other medical reasonsmainly persistent uterine tenderness or vaginal discharge. Planned pregnancy formed an important reason for discontinuation and reflected the age group of our patients (mainly 20-30), who were using the copper 7 for family spacing

Table II shows the net rates for the 368 never-pregnant patients, significant to 33 months of use, and Table III the net rates for the 877 who had been pregnant, significant to 36 months of use. These figures confirm our earlier report ${ }^{2}$ that the pregnancy rate in the neverpregnant group is higher (6.6 at 33 months of use $v 4.7$ at 36 months in the ever-pregnant group). Expulsion rates were not significantly different for the two groups, neither were removals for bleeding or pain plus bleeding. But removals for pain were significantly increased

TABLE I-All insertions: net cumulative closure rates $( \pm S E)$ for use-related terminations (first plus subsequent segments of use) in continuation group at 12, 24, and 36 months of use. Actual numbers of women are given in parentheses

\begin{tabular}{|c|c|c|c|}
\hline Months of use: & 12 & 24 & 36 \\
\hline $\begin{array}{l}\text { Accidental pregnancy } \\
\text { Yearly pregnancy rate } \\
\text { Expulsions } \\
\text { Medical remoyals. }\end{array}$ & $\begin{array}{c}2.7 \pm 0.5(30) \\
2.7 \\
6.4 \pm 0.7(73)\end{array}$ & $\begin{aligned} & 4 \cdot 1 \pm 0.6(44) \\
& 1 \cdot 4 \\
& 7 \cdot 5 \pm 0.8(84)\end{aligned}$ & $\begin{array}{l}5.5 \pm 0.7(55) \\
1.4 \\
9.0 \pm 0.9(96)\end{array}$ \\
\hline $\begin{array}{l}\text { Pain } \\
\text { Bleeding } \\
\text { Pain and bleeding } \\
\text { Other medical removals } \\
\text { Planned pregnancy } \\
\text { Other personal reasons }\end{array}$ & $\begin{array}{l}1.5 \pm 0.4(17) \\
2.2 \pm 0.4(25) \\
2.2 \pm 0.4(24) \\
1.6 \pm 0.4(18) \\
2.8 \pm 0.5(30) \\
2.7 \pm 0.5(30)\end{array}$ & $\begin{array}{l}2.8 \pm 0.5(30) \\
4.5 \pm 0.6(48) \\
4.1 \pm 0.6(44) \\
2.5 \pm 0.5(27) \\
7.0 \pm 0.8(73) \\
6.0 \pm 0.7(63)\end{array}$ & $\begin{aligned} 3.2 & \pm 0.5(33) \\
5.7 & \pm 0.7(58) \\
5.7 & \pm 0.8(55) \\
3.3 & \pm 0.6(33) \\
10.7 & \pm 1.0(100) \\
7.5 & \pm 0.8(74)\end{aligned}$ \\
\hline $\begin{array}{l}\text { Continuation rate } \\
\text { Total No of insertions } \\
\text { Women months of use }\end{array}$ & $\begin{array}{cc} & 77 \cdot 9 \\
1245 \\
10977 \cdot 0\end{array}$ & $\begin{array}{r}61 \cdot 5 \\
18468 \cdot 0\end{array}$ & $22761 \cdot 5$ \\
\hline
\end{tabular}

TABLE II-Insertions in 368 never-pregnant patients: net cumulative closure rates $( \pm S E)$ for use-related terminations (first plus subsequent segments of use) in continuation group at 12,24, and 33 months of use. Actual numbers of women are given in parentheses

\begin{tabular}{|c|c|c|c|}
\hline Month of use: & 12 & 24 & 33 \\
\hline \multirow{2}{*}{$\begin{array}{l}\text { Accidental pregnancy } \\
\text { Yearly pregnancy rate } \\
\text { Expulsions } \\
\text { Medical removals : } \\
\text { Pain } \\
\text { Bleeding } \\
\text { Pain and bleeding } \\
\text { Other medical removals } \\
\text { Planned pregnancy } \\
\text { Other personal reasons }\end{array}$} & $\begin{array}{c}2 \cdot 0 \pm 0 \cdot 8(7) \\
2 \cdot 0 \\
5 \cdot 8 \pm 1 \cdot 3(20)\end{array}$ & $\begin{array}{c}4 \cdot 3 \pm 1 \cdot 1 \\
2 \cdot 3 \\
7 \cdot 0 \pm 1 \cdot 4(24)\end{array}$ & $\begin{array}{c}6.6 \pm 1.4(20) \\
2.3 \\
7.9 \pm 1.5(26)\end{array}$ \\
\hline & $\begin{array}{l}2.9 \pm 0.9(10) \\
2.3 \pm 0.8(8) \\
3.3 \pm 1.6(4) \\
0.9 \pm 0.5(3) \\
2.1 \pm 0.8(7) \\
1.5 \pm 0.7(5)\end{array}$ & $\begin{array}{l}4 \cdot 2 \pm 1 \cdot 1(14) \\
4 \cdot 2 \pm 1 \cdot 1(14) \\
5 \cdot 2 \pm 1 \cdot 2(17) \\
2 \cdot 1 \pm 0.8(7) \\
6 \cdot 7 \pm 1.4(21) \\
3 \cdot 7 \pm 1 \cdot 1(12)\end{array}$ & $\begin{array}{l}4 \cdot 2 \pm 1 \cdot 1(14) \\
5.5 \pm 1.3(17) \\
5 \cdot 6 \pm 1.3(18) \\
2.5 \pm 0.9(8) \\
9 \cdot 1 \pm 1 \cdot 7(27) \\
4 \cdot 2 \pm 1 \cdot 1(13)\end{array}$ \\
\hline $\begin{array}{l}\text { Continuation rate } \\
\text { Women months of use }\end{array}$ & $\begin{array}{r}79 \cdot 2 \\
3449 \cdot 5\end{array}$ & $\begin{array}{r}62 \cdot 6 \\
5756 \cdot 0\end{array}$ & $\begin{array}{r}54.4 \\
6891.5\end{array}$ \\
\hline
\end{tabular}

in the never-pregnant group $(4.2 v 2 \cdot 9)$. In other respects the groups were similar.

Table IV shows the net rates in the replacement group. These 183 patients amassed 3365.0 women months of use, and the rates were significant for a further 22 months of use-that is, 44 months of continuous copper contraception. The pregnancy rate was remarkably low, no pregnancies being recorded until the 21 st month of use. Total expulsions were also few (1.8 at 22 months of use), whereas bleeding was still the main reason for medical removal. This group had a lower planned pregnancy rate $(0.6)$ than the continuation group, reflecting more their desire not to become pregnant rather than a particular medical difference.

Table $\mathrm{V}$ shows the comparison of net rates for the third year of use in the continuation and replacement groups, at " 6 months" and " 12 months"- that is, 30 and 36 months of copper IUD use. To eliminate bias the continuation rate was calculated for medical use-related closures only. The continuation group gave 3965.5 women months of use, the replacement group 1912.0 women months of use.

In contrast to the other tables, table VI shows gross rates because only gross rates can be used to calculate the statistical significance of our results in these two groups of patients. ${ }^{71}$ Statistical analysis, using a Student's $t$ test after Armitage, ${ }^{11}$ on these gross rates gave $P$ values for the individual use-related medical closures. The figures in parentheses represent the number of patients equal to the individual rate.

Three groups of patients were compared: the original 1245 patients at the end of the first year of use (group 1): those who had a new copper

TABLE III-Insertions in 877 patients who had been pregnant: net cumulative closure rates ( $\pm 1 S E)$ (first plus subsequent insertions) in continuation group at 12,24 , and 36 months of use. Actual numbers of women are given in parentheses

\begin{tabular}{|c|c|c|c|}
\hline Month of use: & 12 & 24 & 36 \\
\hline \multirow{2}{*}{$\begin{array}{l}\text { Accidental pregnancy } \\
\text { Yearly pregnancy rate } \\
\text { Expulsions } \\
\text { Medical removals: } \\
\text { Pain } \\
\text { Bleeding } \\
\text { Pain and bleeding } \\
\text { Other medical removals } \\
\text { Planned pregnancy } \\
\text { Other personal reasons }\end{array}$} & $\begin{array}{c}2.9 \pm 0.6(23) \\
2.9 \\
6.6 \pm 0.9(53)\end{array}$ & $\begin{array}{c}3.9 \pm 0.7(30) \\
1 \cdot 0 \\
7 \cdot 7 \pm 1 \cdot 0(61)\end{array}$ & $\begin{array}{c}4 \cdot 7 \pm 0.8(34) \\
0.8 \\
9 \cdot 3 \pm 1 \cdot 1(70)\end{array}$ \\
\hline & $\begin{array}{l}1.1 \pm 0.4(9) \\
1.9 \pm 0.5(15) \\
1.7 \pm 0.5(13) \\
1.9 \pm 0.5(15) \\
3.0 \pm 0.5(23) \\
3.2 \pm 0.6(25)\end{array}$ & $\begin{array}{l}2.4 \pm 0.6(18) \\
4.3 \pm 0.7(32) \\
3.6 \pm 0.7(27) \\
2.6 \pm 0.6(20) \\
7.0 \pm 0.9(52) \\
6.8 \pm 0.9(51)\end{array}$ & $\begin{array}{r}2.9 \pm 0.6(21) \\
5.6 \pm 0.9(40) \\
5.2 \pm 0.8(35) \\
3.5 \pm 0.7(25) \\
10.8 \pm 1.2(71) \\
8.8 \pm 1.1(61)\end{array}$ \\
\hline $\begin{array}{l}\text { Continuation rate } \\
\text { Women months of use }\end{array}$ & $\begin{array}{r}77 \cdot 7 \\
7642 \cdot 5\end{array}$ & $\begin{array}{r}61 \cdot 7 \\
12978 \cdot 0\end{array}$ & $\begin{array}{r}49 \cdot 2 \\
16025 \cdot 0\end{array}$ \\
\hline
\end{tabular}

TABLE IV-Third-year replacement group $(n=183)$ : net cumulative closure rates for first and subsequent insertion at 6, 12, 18, and 22 months of use. Actual numbers are given in parentheses

\begin{tabular}{|c|c|c|c|c|}
\hline Months of use: & 6 & 12 & 18 & 22 \\
\hline $\begin{array}{l}\text { Accidental pregnancy } \\
\text { Expulsions: } \\
\text { Complete } \\
\text { Partial } \\
\text { Medical removals: }\end{array}$ & $\begin{array}{c}0 \\
1 \cdot 2 \pm 0.9(2) \\
0(0) \\
1 \cdot 2 \pm 0.9(2)\end{array}$ & $\begin{array}{c}0 \\
1.2 \pm 0.9(2) \\
0(0) \\
1 \cdot 2 \pm 0.9(2)\end{array}$ & $\begin{array}{c}0 \\
1 \cdot 8 \pm 1.0(3) \\
00(0) \\
1 \cdot 8 \pm 1 \cdot 0(3)\end{array}$ & $\begin{array}{l}0.6 \pm 0.6(1) \\
1.8 \pm 1.0(3) \\
0(0) \\
1.8 \pm 1.0(3)\end{array}$ \\
\hline $\begin{array}{l}\text { Pain } \\
\text { Bleeding } \\
\text { Pain and bleeding } \\
\text { Other medical removals } \\
\text { Planned pregnancy } \\
\text { Other personal reasons }\end{array}$ & $\begin{array}{c}0 \\
1.2 \pm 0.9(2) \\
0.6 \pm 0.6(1) \\
0(0) \\
0(0) \\
0.6 \pm 0.6(1)\end{array}$ & $\begin{array}{l}0.6 \pm 0.6(1) \\
3.0 \pm 1.3(5) \\
1.2 \pm 0.8(2) \\
0.6 \pm 0.6(1) \\
0.0(0) \\
0.6 \pm 0.6(1)\end{array}$ & $\begin{array}{l}0.6 \pm 0.6(1) \\
3.6 \pm 1.5(6) \\
1.8 \pm 1.0(3) \\
0.6 \pm 0.6(1) \\
0.0(0) \\
0.6 \pm 0.6(1)\end{array}$ & $\begin{array}{l}0.6 \pm 0.6(1) \\
3.6 \pm 1.5(6) \\
1.8 \pm 1.0(3) \\
0.6 \pm 0.6(1) \\
0.6 \pm 0.6(1) \\
0.6 \pm 0.6(1)\end{array}$ \\
\hline $\begin{array}{l}\text { Continuation rate } \\
\text { Women months of use }\end{array}$ & $\begin{array}{r}96 \cdot 4 \\
985.5\end{array}$ & $\begin{array}{r}92 \cdot 8 \\
1912 \cdot 0\end{array}$ & $\begin{array}{r}91 \cdot 0 \\
2788 \cdot 0\end{array}$ & $\begin{array}{r}90 \cdot 4 \\
3365 \cdot 0\end{array}$ \\
\hline
\end{tabular}

TABLE V-Comparison of copper 7 during third year of use: net closure rates $( \pm 1 S E)$ in replacement and continuation groups. Actual numbers of women are given in parentheses

\begin{tabular}{|c|c|c|c|c|}
\hline & $\begin{array}{c}\text { Continuation } \\
\text { at } 30 \\
\text { months }\end{array}$ & $\begin{array}{l}\text { Replacement } \\
\text { at } 24+6 \\
\text { months }\end{array}$ & $\begin{array}{c}\text { Continuation } \\
\text { at } 36 \\
\text { months }\end{array}$ & $\begin{array}{l}\text { Replacement } \\
\text { at } 24+12 \\
\text { months }\end{array}$ \\
\hline \multirow{2}{*}{$\begin{array}{l}\text { Accidental pregnancy } \\
\text { Total expulsion } \\
\text { Medical removals: } \\
\text { Pain } \\
\text { Bleeding } \\
\text { Pain and bleeding } \\
\text { Other medical removals } \\
\text { Planned pregnancy } \\
\text { Other personal reasons }\end{array}$} & $\begin{array}{l}1.1 \pm 0.5(5) \\
1.4 \pm 0.6(6)\end{array}$ & $\begin{array}{c}0(0) \\
1 \cdot 2 \pm 0.9(2)\end{array}$ & $\begin{array}{l}3 \cdot 1 \pm 0.9(12) \\
2 \cdot 9 \pm 0.8(12)\end{array}$ & $\begin{array}{c}0(0) \\
1.2 \pm 0.9(2)\end{array}$ \\
\hline & $\begin{array}{l}0.5 \pm 0.3(2) \\
1.8 \pm 0.6(8) \\
1.6 \pm 0.6(17) \\
0.7 \pm 0.4(3) \\
3.7 \pm 0.9(16) \\
1.6 \pm 0.6(7)\end{array}$ & $\begin{array}{c}0(0) \\
1.2 \pm 0.9(2) \\
0.6 \pm 0.6(1) \\
0(0) \\
0(0) \\
0.6 \pm 0.6(1)\end{array}$ & $\begin{array}{l}1.0 \pm 0.5(4) \\
2.9 \pm 0.8(12) \\
4.4 \pm 1.1(16) \\
1.8 \pm 0.7(7) \\
8.6 \pm 1.5(32) \\
4.4 \pm 1.1(16)\end{array}$ & $\begin{array}{c}0.6 \pm 0.6(1) \\
3.0 \pm 1.3(5) \\
1.2 \pm 0.8(2) \\
0.6 \pm 0.6(1) \\
0.0) \\
0.6 \pm 0.6(1)\end{array}$ \\
\hline \multirow{2}{*}{$\begin{array}{l}\text { Continuation rate } \\
\text { Total No of insertions } \\
\text { Women months of use }\end{array}$} & $\begin{array}{c}92 \cdot 9^{*} \\
443\end{array}$ & $97.0^{*}$ & $83 \cdot 2^{*}$ & $93 \cdot 4^{*}$ \\
\hline & & & $3965 \cdot 5$ & $1912 \cdot 0$ \\
\hline
\end{tabular}

* Calculated for medical use-related closures only. 
TABLE VI-All insertions: gross rates $( \pm 1 S E)$ : first and subsequent segments of use

\begin{tabular}{|c|c|c|c|}
\hline & $\begin{array}{c}\text { Group 1 } \\
\text { (after } 1 \text { year) }\end{array}$ & $\begin{array}{c}\text { Group } 2 \\
\text { (third year } \\
\text { replacement) }\end{array}$ & $\begin{array}{c}\text { Group } 3 \\
\text { (third year } \\
\text { continuation) }\end{array}$ \\
\hline \multirow{2}{*}{$\begin{array}{l}\text { Accidental pregnancy } \\
\text { Expulsion } \\
\text { Medical removals: } \\
\text { Pain } \\
\text { Bleeding } \\
\text { Pain and bleeding } \\
\text { Other medical removals } \\
\text { Planned pregnancy } \\
\text { Other personal reasons }\end{array}$} & $\begin{array}{l}3.200 .6(30)^{*} \\
6.90 .8(73)^{*}\end{array}$ & $\begin{array}{c}0.0(0) \\
1 \cdot 2 \pm 0.9(2)^{*}\end{array}$ & $\begin{array}{l}3.8 \pm 1 \cdot 1(12)^{*} \\
3.3=0.9(12)^{*}\end{array}$ \\
\hline & 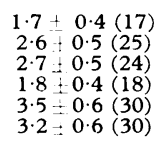 & 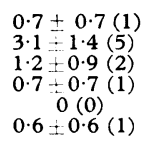 & $\begin{array}{c}1.2+0.6(4) \\
3.30 .9(12) \\
5.31 .3(16)^{*} \\
2.1 .0(7) \\
10.01 .7(32) \\
5.41 .3(16)\end{array}$ \\
\hline $\begin{array}{l}\text { Continuation rate } \\
\text { Women months of use } \\
\text { Total No of insertions }\end{array}$ & $\begin{array}{r}83 \cdot 8 \\
10977 \cdot 0 \\
1245\end{array}$ & $\begin{array}{c}93 \cdot 1 \\
1912 \cdot 0 \\
183\end{array}$ & $\begin{array}{c}81 \cdot 0 \\
3965 \cdot 5 \\
443\end{array}$ \\
\hline
\end{tabular}

*Significant difference between groups (see text).

7 replaced at 24 months and were followed for a further 12 months (group 2); and those who continued with their old copper 7 into the third year (group 3).

By means of Student's $t$ test applied to these gross rates

$$
\mathrm{t}=\frac{\overline{\mathrm{x}}_{1}-\overline{\mathrm{x}}_{2}}{\mathrm{SE}_{1}{ }^{2}-\mathrm{SE}_{2}{ }^{2}}
$$

with $n>200$ degrees of freedom the significance of the difference between the gross rates can be tested. ${ }^{11}$

The difference in pregnancy rate between groups 1 and 2 and 2 and 3 was highly significant: group $1 v$ group $2-t=4.16 ; \mathrm{P}<0.0005$; group $2 v$ group $3-t=3.45 ; \mathrm{P}=<0.0005$. Despite differencesin the size of the groups and women months of use, the pregnancy rate in the replacement group was highly significantly lower than that in the continuation group. With regard to expulsion the difference between group 1 and group 2 was significant: $t=5.0 ; \mathrm{P}=<0.0005$; as was the difference between groups 1 and $3: t=3.0 ; \mathrm{P}=0.0025$. The difference between groups 2 and 3 was probably significant: $t=1.65 ; \mathrm{P}=0.05$. There were no significant differences between the groups for removals for pain and bleeding, whereas there were significantly more removals for pain plus bleeding in group 3 than in group $1(t=1.87 ; \mathrm{P}<0.05)$ and group $2(t=2.59 ; \mathrm{P}<0.01)$. Differences in removals for other medical reasons were not significant.

Cervical smears taken from all the 1245 original patients and the 183 replacement patients were all normal except in one patient who had formerly had a normal smear and after 24 months of use developed dyskaryosis, which was confirmed on a repeat smear. Cone biopsy showed the presence of a carcinoma in situ, which was totally excised. Follow-up smears were normal.

\section{Discussion}

This study-a continuation of our work ${ }^{12}$ - confirms that the copper 7 is an effective medicated IUD, both for nulliparous and multiparous women.

Studies on the release of copper from IUDs show that up to $70^{\circ}$ of the weight of copper is still present after two years of use $^{12}$ and similar amounts after three years. ${ }^{3}$ Figures for the copper T 200 seem to give similar elution rates, ${ }^{13}$ with the highest elution rate being within the first 60 days, the rate then declining to around $60 \mathrm{\mu g} /$ day. Examination of 200 devices removed for various reasons in this study has, however, indicated that over two-thirds weigh more than their original insertion weight after 18 to 36 months of use. Examination under the microscope showed hard deposits of material on the surface of these copper 7 IUDs, which Gosden et $a^{5}$ have shown is a layer of calcium, which would seriously interfere with the contraceptive action of the available copper. This may explain the highly significant difference in the pregnancy rates seen in our two groups-12 pregnancies in the continuation group during the third year of use and no pregnancies in the replacement group. Even allowing for possible differences in the fertility rates of these two groups, which were similar in mean age and parity, this striking difference is remarkable and seems to confirm that although the copper may not be exhausted by three years of use, it may not be available for contraceptive action.

It is interesting that there was no significant difference between the pregnancy rates in group 1 (first 12 months of use) and group 3 (continuation group). While the rates were no different, the reasons for pregnancy were not the same. We have already indicated that many of the pregnancies in group 1 were associated with downward displacement of the IUD and hence a higher pregnancy rate. ${ }^{2}$ Zipper et $a l^{14}$ showed the importance of fundal copper-that is, a normally situated device-in maintaining a low pregnancy rate. One possible reason for the similar pregnancy rate in the continuation group has already been discussed-namely, the lack of available copper for contraceptive use.

The claim of a longer life span with copper sheaths around the copper $T$ (the copper $T$ 220C) instead of copper wire ${ }^{415}$ will have to be re-evaluated, and confirmation of the presence and absence of these calcium deposits on the copper in these devices is needed.

There are two possible reasons for the significantly lower expulsion rate in groups 2 (replacement) and 3 (continuation). Firstly, in a clinical trial the inserters are learning all the time, and, as with any method, their performance will therefore improve. This is particularly true with the copper 7 and expulsion, which is due to the device's failure to open properly when not placed at the fundus. Many of these expulsions were partial and the patient continued to use a new copper 7, retaining the second device. We have previously reported that $62 \%$ continued after a new insertion following a partial expulsion. ${ }^{2}$ Thus the lower expulsion rate in group 3 was partly due to the elimination of these patients who did not have a new insertion after a partial expulsion ( $38^{\circ}$ of all expulsions), while the lower expulsion rate in group 2 may have been due to the improved performance of the inserter and the method of insertion described in our earlier report. ${ }^{2}$

Most of the problems with IUD use (expulsion, pain, and bleeding) seem to occur in the first six months of use with the classical plastic IUDs ${ }^{*}$ and the copper $7,{ }^{1}$ and so replacement of the copper 7 at 24 months of use might be thought to precipitate these problems again. But that has not been our experience: in the 183 patients in the replacement group the medical removal rate was lower than during the first year of use and menstrual disturbance after this second insertion was rare. The second insertion does not seem to affect the patients adversely.

Using the method described in our earlier report ${ }^{2}$ we managed to follow up $98 \%$ of these patients. No further patients were lost to follow-up during this third year of use.

We gratefully acknowledge the help of the doctors and nurses in our family planning clinics, and Dr G Mann and Dr M Cohen of G D Searle and Company. We also thank Mrs P Hessian for her statistical advice and $\mathrm{Mr} \mathrm{M}$ Kilpatrick for designing the computer programme.

\section{References}

${ }^{1}$ Newton, J R, Elias, J, and McEwan, J, Lancet, 1972, 2, 951.

2 Newton, J R, et al, British Medical fournal, 1974, 3, 447.

3 Zipper, J, et al, Contraception, 1976, 13, 7.

${ }^{4}$ Cooper, D C, Miller, A K, and Mishell, D R, American fournal of Obstetrics and Gynecology, 1976, 124, 121.

${ }^{5}$ Gosden, C, Ross, A, and Loudon, N, British Medical fournal, 1977, 1, 202.

${ }^{6}$ Johnson, A B, Maness, R F, and Wheeler, R G, Contraception, 1976, 14, 507.

7 Tietze, C, and Lewit, S, Studies in Family Planning, 1970, 1, 1.

${ }^{8}$ Zipper, J, in Analysis of Intrauterine Contraception, ed F Hefnawi and S J Segal, p 217. Amsterdam, North Holland, 1975.

9 Tietze, C, Studies in Family Planning, 1967, 18, suppl p 1.

10 Potter, R G, Demography, 1966, 3, 297.

11 Armitage, P, Sequential Medical Trials, pp 111, 143. Oxford, Blackwel Scientific, 1975.

12 Stewart, W C, et al, in Analysis of Intrauterine Contraception, ed F Hefnawi and S J Segal, p 149. Amsterdam, North Holland, 1975.

${ }^{13}$ Moo-Young, et al, in Analysis of Intrauterine Contraception, ed F Hefnawi and S J Segal, p 439. Amsterdam, North Holland, 1975.

14 Zipper, J, et al, American fournal of Obstetrics and Gynaecology, 1969, 105, 1274.

15 Tatum, J, in Analysis of Intrauterine Contraception, ed F Hefnawi and S J Segal, p 155. Amsterdam, North Holland, 1975.

(Accepted 23 November 1976) 